\title{
Pelatihan pembuatan pestisida nabati menggunakan buah maja pada kelompok tani Desa Bontotiro di Kabupaten Bantaeng
}

\author{
Nur Anny S. Taufieq ${ }^{1}$, Raeni Tenriola ${ }^{2}$, Dwi Wahyuni Aprianti ${ }^{3}$, \\ Putri Humaira Salsabila ${ }^{4}$, Andriany Ningsih Taufieq ${ }^{5}$ \\ ${ }^{1,2,3}$ Fakultas Teknik, Universitas Negeri Makassar \\ ${ }^{4}$ Fakultas Teknik, Universitas Hasanuddin \\ ${ }^{5}$ MAN 1 Makassar
}

\begin{abstract}
The Community Partnership Program (PKM) partner is the Bontotiro Village Farmer Group of Bantaeng Regency. The problem is the lack of knowledge of the farming community about the use of maja fruits as ingredients for vegetable pesticides. Therefore, farmers need to be equipped with knowledge of how to make vegetable pesticides by using maja fruits. The methods that will be used are mentoring and participatory rural approach (PRA) methods. Assistance methods are used to increase the understanding of the farming community regarding the use of maja fruits as ingredients for vegetable pesticides and to facilitate partners in making vegetable pesticides. The PRA method is carried out to arouse the partner's sense of belonging to the product to be developed, and the partner's sense of responsibility towards the product and the environment around it. The main methods adopted in the Community Partnership Program (PKM) activities are lectures, discussions, questions and answers, and simulations. The results achieved are the maja fruit, which has only been used as household appliances because it has a hard shell. At present, the maja flesh can already be used as a vegetable pesticide, which has high economic value. Making vegetable pesticides using maja flesh is very beneficial for the needs of farmers because it can reduce the use of chemical fertilizers that have an impact on damage to environmental functions and natural resources.
\end{abstract}

Keywords: mentoring, vegetable pesticides, maja fruit, economic value

\section{PENDAHULUAN}

Penggunaan pupuk di dunia terus meningkat seiring dengan meningkatnya kebutuhan masyarakat akan bahan pangan, dan pengurangan waktu panen serta usaha peningkatan hasil pertanian. Kebiasaan petani menggunakan pupuk dan pestisida kimia secara berlebihan berdampak pada kerusakan fungsi lingkungan dan sumber daya alam. Kebijakan ditingkat internasional telah mendorong pemerintah Indonesia mengeluarkan kebijakan nasional dalam perlindungan tanaman, untuk menggalakkan program Pengendalian Hama Terpadu (PHT) dengan mengutamakan pemanfaatan agens pengendalian hayati atau biopestisida termasuk pestisida nabati sebagai komponen utama dalam sistem PHT yang dituangkan dalam Peraturan Pemerintah No. 6 tahun 1995. Untuk mengurangi penggunaan pupuk kimia secara berlebihan, pemerintah telah membuat kebijakan tentang rekomendasi penggunaan pupuk yaitu permentan No 40. Tahun 2007. Indonesia merupa- kan salah satu Negara yang memiliki keanekaragaman hayati yang cukup tinggi, sehingga sumber daya alam melimpah untuk mendukung kehidupan manusia. Berbagai jenis tumbuhan yang ada berpotensi untuk dijadikan sebagai pupuk dan pestisida nabati. jenis-jenis tumbuhan yang dapat dijadikan sebagai pupuk nabati/organik (biofertilizer) yaitu eceng gondok (Eichornia crassipes), buah nanas (Ananas sativus). Sedangkan pestisida nabati (biopesticides) adalah buah maja (Aegle marmelos) dan jarak pagar (Jantropha curcas). Penggunaan berbagai jenis tumbuhan lokal sebagai pupuk dan pestisida nabati merupakan salah satu cara dalam mendukung konsep pertanian berkelanjutan (sustainable agriculture) (Aryantha, 2002).

Pertanian berkelanjutan (sustainable agriculture) adalah pertanian yang berlanjut untuk saat ini dan saat yang akan datang dan selamanya, Artinya pertanian tetap ada dan bermanfaat bagi semuanya dan tidak menimbulkan bencana bagi 
semuanya. Jadi dengan kata lain pertanian yang bisa dilaksanakan saat ini, saat yang akan datang dan menjadi warisan yang berharga bagi anak cucu kita. Ada pun definisi lain dari sistem pertanian berkelanjutan adalah sebagai alternatif-alternatif untuk mencapai tujuan sistem produksi pertanian yang dapat menguntungkan secara ekonomi dan aman secara lingkungan. Sistem pertanian Berkelanjutan juga dapat diartikan sebagai keberhasilan dalam mengelola sumberdaya untuk kepentingan pertanian dalam memenuhi kebutuhan manusia, sekaligus mempertahankan dan meningkatkan kualitas lingkungan serta konservasi sumberdaya alam (Sutanto, 2002).

Tujuan pertanian berkelanjutan adalah mempertahankan dan meningkatkan kesuburan tanah; meningkatkan dan mempertahankan hasil pertanian secara optimal; mempertahankan dan meningkatkan keanekaragaman hayati dan ekosistem; dan yang lebih penting untuk mempertahankan dan meningkatkan kesehatan penduduk dan makhluk hidup lainnya. Sistem pertanian berkelanjutan adalah pengelolaan sumber daya yang berhasil untuk usaha pertanian guna membantu kebutuhan manusia sekaligus mempertahankan dan meningkatkan kualitas lingkungan dan melestarikan sumber daya alam. Pertanian berkelanjutan merupakan pengelolaan konservasi sumber daya alam dan berorientasi pada perubahan teknologi dan kelembagaan yang dilakukan sedemikian rupa untuk menjamin pemenuhan dan pemuasan kebutuhan manusia secara berkelanjutan bagi generasi sekarang dan mendatang.

Karwan (2003) menyatakan bahwa konsep dasar sistem pertanian berkelanjutan adalah memper-tahankan ekosistem alami lahan pertanian yang sehat, bebas dari bahan-bahan kimia yang meracuni lingkungan. Sistem pertanian berkelanjutan pada hakikatnya adalah kembali pada alam yaitu sebuah sistem pertanian yang tidak merusak, tidak mengubah serasi, selaras dan seimbang dengan lingkungan atau sistem pertanian yang patuh pada kaidah-kaidah alamiah. Kata 'berkelanjutan' digunakan secara luas dalam lingkup program pembangunan yang diartikan menjaga agar suatu upaya terus berlangsung atau kemampuan untuk bertahan dan menjaga agar tidak merosot.

Dalam sistem pertanian, berkelanjutan memiliki pengertian pengelolaan sumber daya alam yang berhasil untuk usaha pertanian dalam membantu kebutuhan manusia yang berubah sekaligus mempertahankan atau meningkatkan kualitas lingkungan dan melestarikan sumber daya alam. Sistem pertanian berkelanjutan meliputi komponen fisik, biologi dan sosial ekonomi. Pertanian berkelanjutan direpresentasikan dengan sistem pertanian yang melaksanakan pengurangan input bahanbahan kimia, mengendalikan erosi tanah, gulma, serta memelihara kesuburan tanah (Saragih, 2008).

Salah satu jenis tumbuhan yang dapat dijadikan sebagai pestisida nabati (biopesticides) adalah buah maja (Aegle marmelos). Maja (Aegle mermelos L.) merupakan tanaman dari suku jerukjerukan atau rutaceae yang penyebarannya tumbuh diantara dataran rendah hingga ketinggian $\pm 500 \mathrm{~m}$ dpl. Tumbuhan ini terdapat di Negara Asia Tenggara termasuk Indonesia. Pohon maja mampu tumbuh dilahan basa seperti rawa-rawa maupun dilahan kering dan ekstrim, pada suhu $49^{\circ} \mathrm{C}$. Pada musim kemarau hingga $-7^{\circ} \mathrm{C}$ pada musim dingin di Punjab (India), pada ketinggian tempat mencapai diatas $1.200 \mathrm{~m}$.

Maja merupakan tanaman perdu, dengan kulit buah berwarna hijau sebesar bola voli dan memiliki kulit tempurung yang sangat keras, bahkan dua kali lebih keras dari tempurung kelapa sehingga tempurung buah maja digunakan sebagai perkakas rumah tangga mulai dari gayung air, takaran beras, serta tempat penyimpanan aneka biji-bijian.

Buah maja terdiri dari zat lemak dan minyak terbang yang mengandung linonen. Daging buah mengandung substansi semacam minyak balsem, 2-furo-coumarins-psoralen dan marmelosia $\left(\mathrm{C}_{13} \mathrm{H}_{12} \mathrm{O}\right)$. Buah, akar dan daun bersifat antibiotik. Buah maja juga mengandung marmelosin minyak atsiri, pektin, saponin dan tanin. Senyawa saponin merupakan glikosida yang memiliki aglikon berupa steroid dan triterpen. Saponin steroid tersusun atas inti steroid $\left(\mathrm{C}_{27}\right)$ dan molekul karbohidrat (Rismayani, 2013). 
Steroid saponin dihidrolisis menghasilkan suatu aglikon yang dikenal sebagai saraponin. Saraponin triterpenoid tersusun atas inti triterpenoid dengan molekul karbohidrat, dan apabila dihidrolisis menghasilkan suatu aglikon yang disebut sapogenin. Molekul yang dimiliki saponin inilah sehingga menyebabkan buah maja berasa pahit, berbusa bila dicampur dengan air, mempunyai sifat anti eksudatif, mempunyai sifat inflamatori dan mempunyai sifat haemolisis (merusak sel darah merah). Senyawa tanin merupakan salah satu senyawa rasanya pahit yang bereaksi dengan protein, asam amino dan alkaloid yang mengandung banyak gugus hidroksil dan karboksil untuk membentuk perikatan kompleks yang kuat dengan protein dan makromolekul yang lain sehingga rasanya yang sangat pahit tidak disukai serangga yang menjadi hama pada tanaman.

Desa Bontotiro merupakan salah satu wilayah di Kecamatan Sinoa Kabupaten Bantaeng Sulawesi Selatan, luas wilayah $4.91 \mathrm{~km}^{2}$ dan jumlah penduduknya sebesar 12.274 jiwa. Desa Bontotiro merupakan salah satu desa yang memiliki banyak tanaman maja. akan tetapi pemanfaatan buah tanaman tersebut masih kurang diketahui oleh warga sekitar. Olehnya itu, diperlukan adanya sosialisasi dan pelatihan pembuatan pestisida nabati dengan memanfaatkan buah maja. Sosialisasi dan pelatihan ini dapat melibatkan pemerintah daerah dan warga masyarakat khususya petani di Desa Bontotiro.

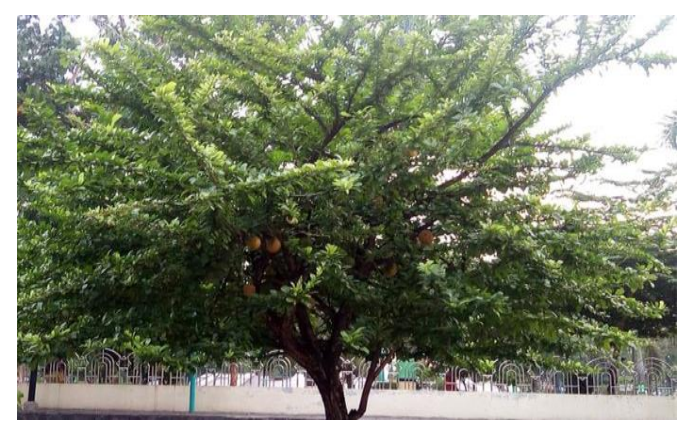

Gambar 1. Tanaman maja
Dari pemaparan analisis situasi tersebut di atas, dapat kami diidentifikasi permasalahan yang dihadapi oleh mitra yaitu kurangnya pengetahuan masyarakat petani akan pemanfaatan buah maja sebagai bahan pembuat pestisida nabati. Oleh karena itu masyarakat petani perlu dibekali pengetahuan bagaimana cara pembuatan pestisida nabati dengan memanfaatkan buah maja.

\section{METODE PELAKSANAAN}

Pada pelaksanaan kegiatan program kemitraan masyarakat ini, metode yang akan dilakukan berupa metode pendampingan (mentoring) dan metode partisipatory rural approach (PRA). Metode pendampingan dilakukan untuk meningkatkan pemahaman masyarakat petani mengenai pemanfaatan buah maja sebagai bahan pembuat pestisida nabati dan memfasilitasi mitra dalam pembuatan pestisida nabati. Metode PRA dilakukan untuk membangkitkan rasa memiliki (sense of belonging) mitra terhadap produk yang akan dikembangkan, dan rasa tanggungjawab (sense of responsibility) mitra terhadap produk dan lingkungan yang ada di sekitarnya.

Metode utama yang ditempuh dalam kegiatan Program Kemitraan Masyarakat (PKM) ini adalah: 1. Pada waktu penyajian materi penyuluhan, metode yang digunakan adalah ceramah, diskusi, tanya jawab dan simulasi.

2. Pada saat latihan pembuatan pestisida nabati, metode yang digunakan adalah demonstrasi.

\section{HASIL DAN PEMBAHASAN}

\section{A. Memperkenalkan Alat dan Bahan Pestisida Nabati}

Pada tahapan ini, tim pengabdi memperlihatkan kepada mitra alat-alat yang digunakan untuk pembuatan pestisida nabati. Setelah itu dilanjutkan dengan memperkenalkan bahan-bahan yang digunakan untuk pembuatan pestisida nabati tersebut. 


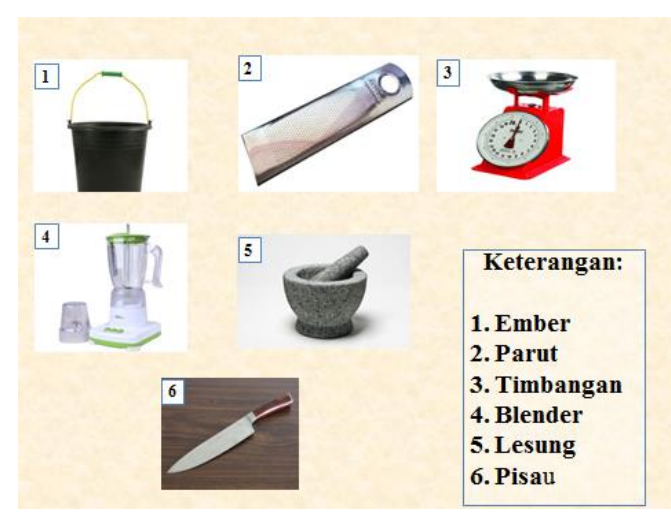

Gambar 2. Alat-alat yang digunakan untuk pembuatan pestisida nabati

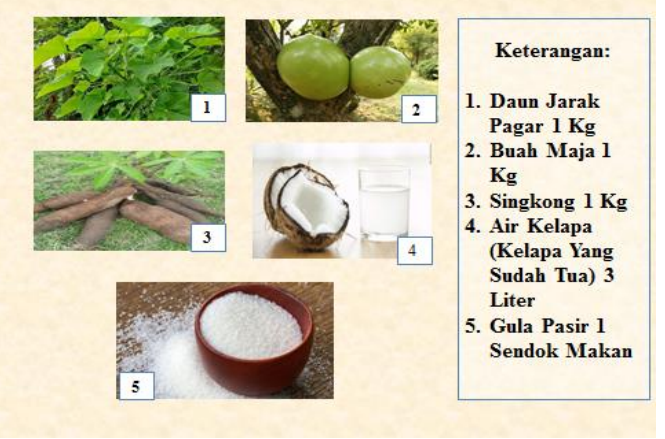

Gambar 3. Bahan-bahan yang digunakan untuk pembuatan pestisida nabati

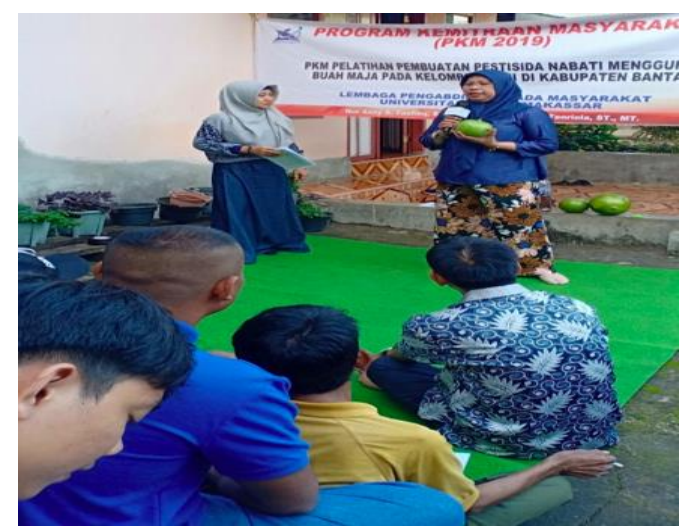

Gambar 4. Memperkenalkan buah maja sebagai bahan utama pestisida nabati

\section{B. Penyampaian Materi}

Pada tahap ini tim pengabdi menyampaikan materi kepada mitra bagaimana cara memanfaatkan hasil lingkungan sekitar menjadi sesuatu yang bernilai tinggi, salah satunya memanfaatkan buah maja sebagai pestisida nabati.

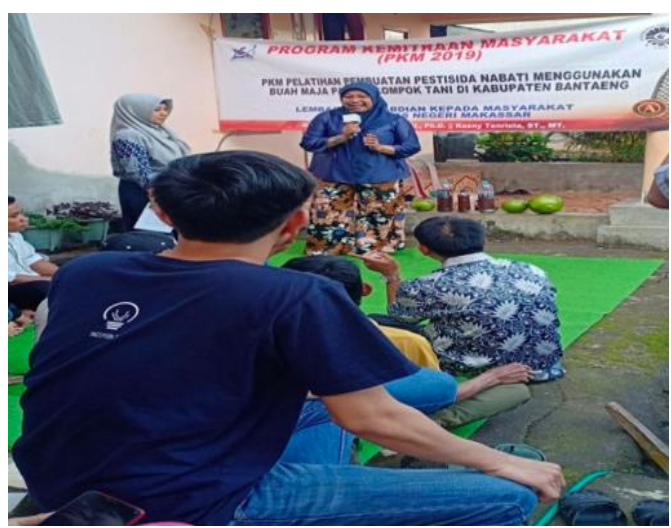

Gambar 5. Penyampaian materi cara pembuatan pestisida nabati

\section{Hasil Kegiatan}

Hasil kegiatan pengabdian pada masyarakat yang telah dilakukan dapat menyelesaikan beberapa permasalahan mitra sehingga kegiatan ipteks bagi masyarakat yang dilakukan dapat dikatakan berhasil. Adapun hasil kegiatan yang telah dilakukan sebagai berikut:

1. Buah maja tanaman yang berwarna hijau yang memiliki kulit tempurung yang sangat keras, bahkan dua kali lebih keras dari tempurung kelapa sehingga tempurung buah maja biasa digunakan sebagai perkakas rumah tangga mulai dari gayung air, takaran beras, serta tempat penyimpanan aneka biji-bijian, sedangkan daging buah maja dibuang percuma. Saat ini daging buah maja sudah bisa dimanfaatkan sebagai pestisida nabati yang memiliki nilai ekonomis tinggi.

2. Bahan yang digunakan untuk pengolahan daging buah maja menjadi pestisida nabati antara lain daun jarak pagar $1 \mathrm{~kg}$, daging buah maja $1 \mathrm{~kg}$, singkong $1 \mathrm{~kg}$, air kelapa (menggunakan kelapa yang sudah tua) sebanyak 3 liter dan gula pasir 1 sendok.

3. Pembuatan pestisida nabati menggunakan daging buah maja sangat bermanfaat bagi kebutuhan petani karena dapat mengurangi penggunaan pupuk kimia yang berdampak pada kerusakan fungsi lingkungan dan sumber daya alam.

4. Peserta sangat termotivasi untuk mengikuti seluruh rangkaian kegiatan program kemitraan 
masyarakat ini mulai dari awal sampai kegiatan ini berakhir.

5. Peserta sangat antusias mengikuti materi dan pelatihan karena apa yang diberikan oleh pemateri sangat membantu mereka dalam meningkatkan pengetahuan bagaimana memanfaatkan sumber daya alam yang ada di sekitar sehingga menghasilkan sesuatu yang sangat bermanfaat. Contohnya pemanfaatan buah maja sebagai pestisida nabati.

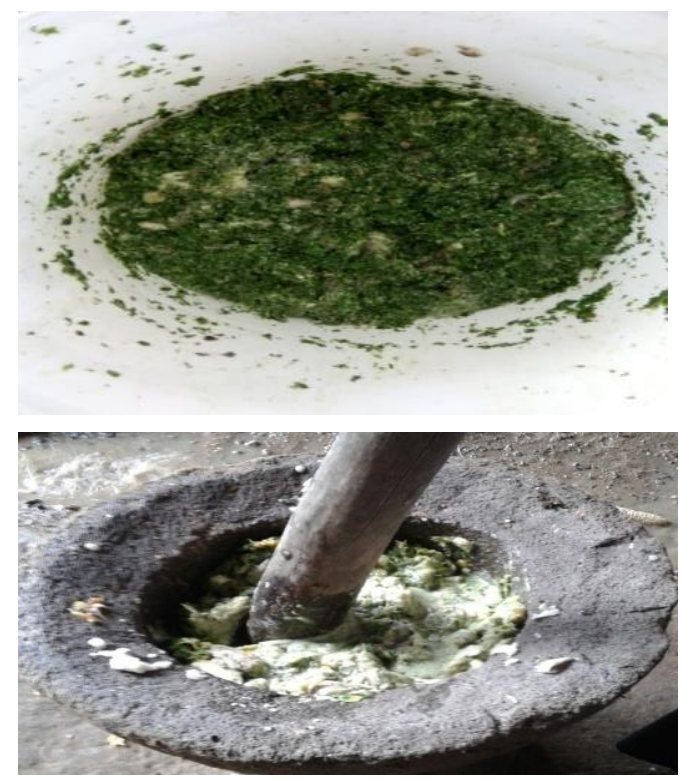

Gambar 6. Proses penghalusan buah maja dan daun jarak pagar

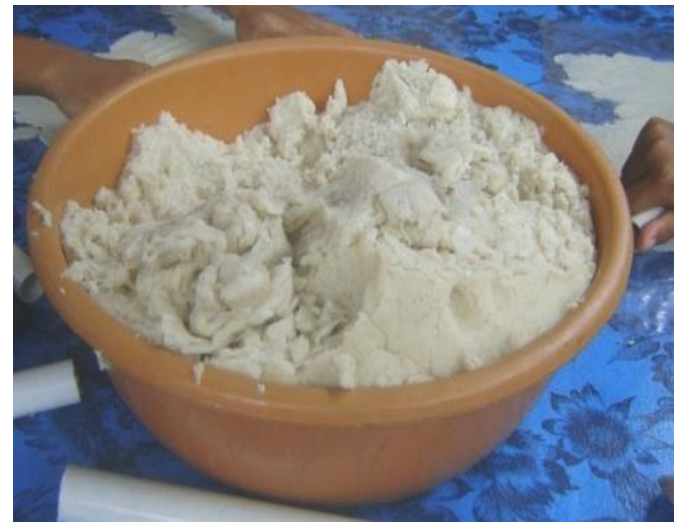

Gambar 7. Singkong yang dihaluskan

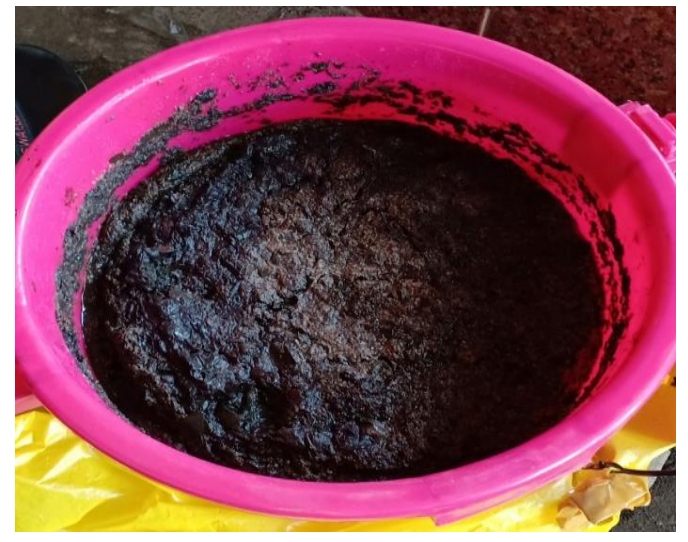

Gambar 8. Hasil fermentasi semua bahan pembuatan pestisida nabati

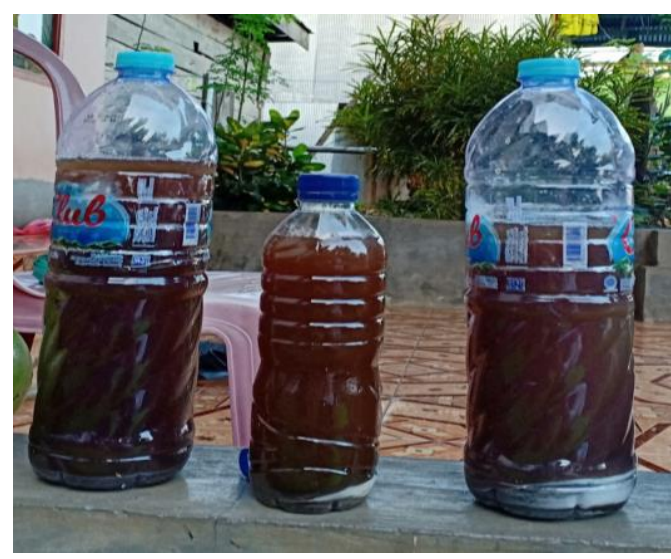

Gambar 9. Pestisida nabati setelah disaring dari hasil fermentasi selama kurang lebih 1-2 minggu

\section{KESIMPULAN}

Dari hasil kegiatan Program Kemitraan Masyarakat, dapat disimpulkan bahwa:

1. Petani Desa Bontotiro Kabupaten Bantaeng sudah memiliki pengetahuan akan manfaat lain dari buah maja dan keterampilan dalam pengolahan buah maja menjadi pestisida nabati.

2. Dengan adanya kegiatan pelatihan pembuatan pestisida nabati menggunakan buah maja tersebut, dapat menghemat biaya pembelian pupuk serta mengurangi penggunaan pupuk kimia secara berlebihan yang dapat berdampak negatif bagi lingkungan dan sumber dalam alam. 


\section{UCAPAN TERIMA KASIH}

Program Kemitraan Masyarakat ini dapat terselenggara atas bantuan, arahan, dan dukungan moral maupun material dari berbagai pihak. Untuk itu ucapkan terima kasih kami ucapkan kepada:

1. Rektor Universitas Negeri Makassar selaku pembina Universitas Negeri Makassar.

2. Ketua Lembaga Pengabdian Masyarakat Universitas Negeri Makassar dan Pemerintah Kabupaten Bantaeng, atas izin dan dukungannya dalam melakukan kegiatan program kemitraan masyarakat ini.

3. Semua pihak yang telah membantu dalam pelaksanaan kegiatan program kemitraan masyarakat ini yang tidak sempat kami sebut namanya satu persatu.

\section{DAFTAR PUSTAKA}

Aryantha, I.P. 2002. Development of Sustainable Agricultural System, One Day Discussion on The Minimization of Fertilizer Usage. Menristek- BPPT. Jakarta., http://hayati.itb.ac.id/artkel/pertanianbermoral.pdf. $\quad 30$ Februari 2019.

Karwan, S.A. 2003. Sistem Pertanian Berkelanjutan. Yogyakarta: Karnisius.

Rismayani. 2013. Manfaat buah Maja sebagai Pestisida Nabati untuk Hama Penggerek Buah Kakao (Conopomorpha cramerella). Warta Penelitian dan Pengembangan Tanaman Industri 19 (3): 24-26.

Saragih, S.E. 2008. Pertanian Organik. Solusi Hidup Harmoni dan Berkelanjutan. Jakarta: Penebar Swadaya.

Sutanto, R. 2002. Pertanian Organik, Menuju Pertanian Alternatif Berkelanjutan. Yogyakarta: Penerbit Kanisius. 